His service to the linguistic interpretation of Iranian was great, ranging from a study of Avestan ("Sound-system of the Avesta", Irano-Dardica, 31--83) to modern Afghan literature (as on Khushhal Khān in 1945). We can also expect a posthumous publication of a revision of his early work, the Etymological vocabulary of Pashto (Oslo, 1927). He was generous to younger Iranists in giving them his own collections of materials, as of Wanetsi to J. Elfenbein and of Kafiri to G. Fussman.

His passing has bereft us of a valued counsellor in Iranica and a fruitful source of important studies on Iranian and North-west-frontier languages. Personally he was a delight to meet.

H. W. BAILEY.

\title{
BERNHARD KARLGREN: IN MEMORIAM
}

With the death of Bernhard Karlgren on 20 October 1978, an era of Sinology, which began in the last year of the Chinese empire, has come to an end. Karlgren's scholarly activities spanned over seven decades. His first work, a phonetic transcription of folk tales from two districts in his native Swedish province, was published in 1908. His last work, "Moot words in some Chuang Tse chapters", appeared in the 1976 issue of the Bulletin of the Museum of Far Eastern Antiquities. When I visited Karlgren on his 89th birthday, on 5 October 1978, I found on his desk preparatory notes for a paper on a philological problem in the Book of odes.

The truly awe-inspiring scholarly production of Bernhard Karlgren contains a long series of brilliant works which for all time will stand out as great landmarks in Western Sinology. His Etudes sur la phonologie chinoise (1915-26), which contains his reconstruction of Ancient Chinese, laid the foundation for the disciplines of modern Chinese dialectology and historical phonology. Basing himself on the impressive results achieved by the brilliant philologists of the Ch'ing period, Karlgren was able to formulate a reconstruction of Archaic Chinese. The results of his researches, which were presented in a series of works in the years 1925-40, were summed up in his Grammata serica (1940), Compendium of phonetics in Ancient and Archaic Chinese (1954), and Grammata Serica recensa (1957).

Bernhard Karlgren's reconstruction of Archaic Chinese opened up new approaches to the study of early Chinese texts. His glosses on the Book of odes $(1942,1944,1946)$ and on the Book of documents (1948) are brilliant contributions in the field of classical Chinese philology. The monumental monograph Loan characters in pre-Han texts (1967) will necessitate considerable revisions in the field of Chinese lexicography. 
Modern Chinese is said to be a typical representative of the isolating languages, by which characterization is meant that the interrelationship of the words in a sentence is marked, not by changes in the forms of the words, but solely by their relative positions and connective words. In "Le proto-chinois, langue flexionelle" (1920) and "Word families in Chinese" (1933) Karlgren was able to prove that the Chinese language at an early stage was characterized by a number of morphological processes which have long ceased to be productive. Karlgren's researches into the phonology and morphology of Proto-Chinese and Archaic Chinese have important bearings on comparative Sino-Tibetan studies.

Among Karlgren's most important works must be mentioned "On the authenticity and nature of the Tso Chuan" (1926), "The authenticity of Ancient Chinese texts" (1929), "The early history of the Chou Li and Tso Chuan texts" (1931), and "Legends and cults in ancient China" (1946). With these works Karlgren laid the foundations for a critical methodology, without the aid of which any attempt to investigate the documentation on early Chinese civilization is bound to fail.

Bernhard Karlgren had a singular capacity for extending his strict linguistic and philological methodology to other fields of research. His comparative studies of the decoration of early Chinese bronzes led to important revisions of the traditionally accepted chronology.

His scholarly activities were not confined to his own research. As ViceChancellor of Gothenburg University (1931-6), Director of the Museum of Far Eastern Antiquities (1939-59), President of the Royal Academy of Letters, History, and Antiquities (1956-64), and Chairman of the Swedish Foundation of Humanities (1954-9) he played a very significant role as a supporter and organizer of research in a great many fields.

Bernhard Karlgren's brilliant intellect, irrepressible energy, encyclopaedic knowledge, great learning, and devotion to scholarship made him one of the greatest scholars of his time. Those who knew Bernhard Karlgren solely through his works may have gained the impression that he was a stern and withdrawn scholar. His disciples who knew him as a teacher and friend of great human warm th and compassion venerated and loved him.

N. G. D. MALMQVIST. 